\title{
Comparison of antiemetic efficacy of palonosetron, ondansetron and granisetron in prevention of postoperative nausea and vomiting
}

\author{
Neha Sharma $^{1}$, Manjula Bhargava ${ }^{1}$, Vineet Chaudhary ${ }^{2}$, Dhruva Sharma $^{3}$, Ajitesh Mishra ${ }^{1}$, \\ Pankaj K. Chaudhary ${ }^{4}$, Uma Advani ${ }^{5}$, Shobha Kulshreshtha ${ }^{6}$
}

\author{
${ }^{1}$ Department of Pharmacology, NIMS Medical College \& Hospital, Jaipur, Rajasthan, India \\ ${ }^{2}$ Department of General Surgery, NIMS Medical College \& Hospital, Jaipur, Rajasthan, India \\ ${ }^{3}$ Department of Cardiothoracic Surgery, SMS Medical College, Jaipur, Rajasthan, India \\ ${ }^{4}$ Department of Pharmacology, U.P. Rural Institute of Medical Science \& Research, Etawah, Uttar Pradesh, India \\ ${ }^{5}$ Department of Pharmacology, SMS Medical College \& Hospital, Jaipur, Rajasthan, India \\ ${ }^{6}$ Department of Pharmacology, ITS Dental College \& Hospital, Noida, Uttar Pradesh, India
}

Received: 15 July 2015

Revised: 17 July 2015

Accepted: 19 August 2015

\author{
*Correspondence: \\ Dr. Neha Sharma, \\ E-mail: nsharma226@gmail.com
}

Copyright: (c) the author(s), publisher and licensee Medip Academy. This is an open-access article distributed under the terms of the Creative Commons Attribution Non-Commercial License, which permits unrestricted non-commercial use, distribution, and reproduction in any medium, provided the original work is properly cited.

\begin{abstract}
Background: Postoperative nausea and vomiting (PONV) was termed "the big little problem" nearly a quarter century ago in an editorial. The past decade has witnessed the introduction of several significant innovations to combat PONV, but it still remains as big a problem as before because newer choices and confusions over standardization added side by side. The aim of this study is to compare the efficacy of palonosetron with that of granisetron and ondansetron in the treatment and prevention of postoperative nausea and vomiting after laparoscopic cholecystectomy.

Methods: This randomized prospective comparative clinical study was carried out in the NIMS Medical College \& Hospital, NIMS University, Jaipur, during the period of January 2013 to December 2013 amongst female patients of ASA grade I and II (ASA = American Society of anesthesiology), scheduled for laparoscopic cholecystectomy under general anesthesia. A total number of 90 patients were selected and randomized into three groups of 30 patients each. Group-I was given inj. palonosetron $(0.25 \mathrm{mg})$, Group-II was given inj. granisetron $(1 \mathrm{mg})$ and Group-III was given inj. ondansetron $(8 \mathrm{mg}$ ). One way analysis of variance (ANOVA) and Pearson's Chi-square test were done as the tests of significance whenever applicable to compare the mean of different groups.

Results: The incidence of nausea was $10 \%$ in Palonosetron-group while it was found to be $60 \%$ in Ondansetrongroup. The incidence of vomiting was $6.7 \%$ in group-I, $26.6 \%$ in group-II \& $53.3 \%$ in group-III respectively. The difference was statistically significant between group I vs group II ( $\mathrm{p}<0.05) .13 .3 \%$ of patients in Palonosetron-group required rescue antiemetic, while in Ondansetron-group, it was $46.7 \%$.

Conclusions: To conclude, palonosetron greatly reduced the incidence of postoperative nausea and vomiting, and also the requirement of rescue antiemetic in postoperative period than granisetron and ondansetron. Patients were satisfied by using this drug. Palonosetron is more effective in comparison to granisetron and ondansetron in the prevention and treatment of postoperative nausea and vomiting after laparoscopic cholecystectomy.
\end{abstract}

Keywords: Post-operative nausea and vomiting, Palonosetron, Granisetron, Ondansetron 


\section{INTRODUCTION}

The first surgery under general anesthesia was performed successfully on $16^{\text {th }}$ October, 1846. Post-Operative Nausea and Vomiting (PONV) has first extensive descriptions by Sir John Snow in 1848, within 18 months of chloroform introduction in anesthesia. Since then, in less than 170 years almost, at least 102 editorials have been published in Medline-indexed journals focusing on PONV. ${ }^{1}$

PONV was termed "the big little problem" nearly a quarter century ago in an editorial. ${ }^{2}$ The past decade has witnessed the introduction of several significant innovations to combat PONV, particularly the introduction of serotonin antagonists and the use of combinations of drugs for analgesia and control of PONV. ${ }^{3}$ But it still remains as big a problem as before because newer choices and confusions over standardization added side by side. ${ }^{3}$

Actually the avoidance of Post-Operative Nausea and Vomiting (PONV) is very important from the patient's perspective $^{4}$ - some studies report PONV up to $85 \% .^{5}$ And this data is here when "PONV in routine clinical care is likely to be underreported". 6

PONV also has cost implications in terms of nursing time, delayed recovery, hospital resources and possible re-operation costs. ${ }^{7-9}$ Thus right now PONV is one of the most common and distressing complication of surgery under general anesthesia ${ }^{10}$ and thereby, PONV is still important in epidemiological and financial terms. ${ }^{11}$

A triple comparison of ondansetron, granisetron and metoclopramide is already there ${ }^{12}$ but triple comparison among 5-HT3 antagonists is not available. That's why comparing these two against a new entity of palonosetron is the aim of this study.

\section{Aim and objectives}

1. To compare the efficacy of palonosetron with that of granisetron and ondansetron in the treatment and prevention of postoperative nausea and vomiting after laparoscopic cholecystectomy.

2. To observe the incidence of nausea and vomiting separately in the postoperative period,

3. To observe the requirement of rescue antiemetic,

4. To find out the haemodynamic stability (heart rate and systolic/ diastolic blood pressure)

5. To detect the patients satisfaction by verbal rating scale after 24 hours of surgery.

\section{METHODS}

After taking permission from the institutional ethical committee, this randomized prospective clinical study was carried out in the NIMS Medical College \& Hospital, Jaipur, during the period of January 2013 to December 2013.

\section{Inclusion criteria}

1. Female patients aged between $30-50$ years

2. ASA grade I and II (ASA = American Society of Anesthesiology)

3. Scheduled for laparoscopic cholecystectomy under general anesthesia

\section{Exclusion criteria}

1. Females with known history of hypersensitivity to study drugs,

2. Gastrointestinal diseases,

3. Who had taken antiemetics within 24 hours before surgery,

\section{Receiving hormonal therapy}

5. Pregnant and menstruating patients.

A total number of 90 patients, sex female, age range 3050 years undergoing laparoscopic cholecystectomy were selected by sequential sampling (automatically randomized by inclusion/exclusion criteria and previously unknown sequence of enrolment for surgery). They were equally divided into three groups of 30 patients.

Group-I was given inj. palonosetron $(0.25 \mathrm{mg})^{13,14}$ - as 5 $\mathrm{ml}$ vial containing $0.25 \mathrm{mg}$ of the drug was procured and $5 \mathrm{ml}$ of the preparation was used as a single bolus.

Group-II was given Inj. granisetron $(1 \mathrm{mg})^{15,16}$ - as $1.0 \mathrm{ml}$ vial containing $1 \mathrm{ml}$ of the drug was procured and was used as a single bolus.

Group-III was given inj. ondansetron $(8 \mathrm{mg})^{12,17}$ - as $4 \mathrm{ml}$ vial containing $2 \times 4=8 \mathrm{mg}$ of the drug was procured and $4 \mathrm{ml}$ of the preparation was used as a single bolus.

Patients' data were collected in prescribed forms containing patients' particulars, preoperative baseline (pulse, blood pressure-systolic and diastolic blood pressure) parameters, preoperative and postoperative parameters including nausea, vomiting, patients' satisfaction by 4 points VRS (Verbal Rating Scale) and use of rescue antiemetics. 
Patients were monitored preoperatively and postoperatively. In postoperative room proper hydration was maintained. Analgesia was maintained by injection pethidine $(1.5 \mathrm{mg} / \mathrm{kg})$ given intramuscularly 8 hourly in each patient, injection ketorolac $(30 \mathrm{mg})$ intramuscularly was given on patient's demand.

The 24 hours study period started upon entry to the postoperative room. Patients were observed at 30 minutes, 1 hour, 2 hours, 4 hours, 8 hours, 16 hours and 24 hours after recovery.

In this period hemodynamic parameters (pulse, systolic and diastolic blood pressure), arterial oxygen saturation, the number and time of nausea and vomiting and rescue antiemetic treatment were recorded. Injection antiemetic was given according to the patient's need. Patient satisfaction was recorded by 4 points verbal rating scale 24 hours after recovery.

\section{Statistical analysis}

All the variables were expressed as mean $\pm \mathrm{SD}$. One way analysis of variance (ANOVA) and Pearson's Chi-square $\left(\chi^{2}\right)$ test were done as the tests of significance whenever applicable to compare the mean of different groups. The statistical analysis was done by using SPSS program. Pvalue $<0.05$ was considered as significant.

\section{RESULTS}

Observation of the present study was analyzed in the light of comparison among each subject groups. The groups became statistically matched for age $(\mathrm{P}=0.948)$, weight $(\mathrm{P}=0.908)$ i.e. there was no significant difference among the study groups as shown in the Table 1.

\section{Nausea}

The incidence of nausea was $10 \%$ in group-I, $33.3 \%$ in group-II \& $60 \%$ in group-III respectively as shown in Table 2/Figure 1.

\section{Vomiting}

As shown in Table 3/Figure 2, the incidence of vomiting was $6.7 \%$ in group-I, $26.6 \%$ in group-II \& $53.3 \%$ in group-III respectively. The difference was statistically significant between group I vs. group II $(\mathrm{p}<0.05)$.

\section{Patient satisfaction}

As shown in Table 4, overall patient satisfaction in 24 hours in post-operative period by Verbal Rating Scale (VRS). After 24 hours overall patient satisfaction was assessed. In group-I, 1 patients rated "not effective at al", 6 "moderate effective", 11 "effective" and 12 "excellent".

Table 1: Age and body weight distribution amongst different study groups $(\mathrm{n}=90)$.

\begin{tabular}{|llllll|}
\hline Variable & Group- $\mathbf{1}(\mathbf{n}=\mathbf{3 0})$ & Group-2 $(\mathbf{n}=\mathbf{3 0})$ & Group-3 $(\mathbf{n}=\mathbf{3 0})$ & f-statistic & P-value \\
\hline Age (years) & $37.3 \pm 2.06$ & $36.7 \pm 1.82$ & $37.5 \pm 1.49$ & 1.59 & \&gt; 0.05 \\
\hline Weight $(\mathrm{kg})$ & $53.5 \pm 1.38$ & $54.4 \pm 1.90$ & $54.4 \pm 1.88$ & 2.68 & \&gt; 0.05 \\
\hline
\end{tabular}

Table 2: Incidence of nausea between different study groups $(n=90)$.

\begin{tabular}{|llllll|}
\hline Groups & $\mathbf{n}$ & No nausea & Nausea & $\begin{array}{l}\text { Chi-square } \\
\text { value }\end{array}$ & P value \\
\hline I (Palonosetron Group) & $\mathrm{n}=30$ & $27(90.0 \%)$ & $3(10.0 \%)$ & & \\
\hline II (Granisetron Group) & $\mathrm{n}=30$ & $20(66.7 \%)$ & $10(33.3 \%)$ & 16.632 & $0.00024 \mathrm{p} \& 1 \mathrm{lt} ; 0.05$. \\
\hline III (Ondansetron Group) & $\mathrm{n}=30$ & $12(40.0 \%)$ & $18(60.0 \%)$ & & \\
\hline Total & 90 & $59(62.2 \%)$ & $31(34.4 \%)$ & & \\
\hline
\end{tabular}

Table 3: Incidence of vomiting in different study group $(n=90)$.

\begin{tabular}{|c|c|c|c|c|c|}
\hline Groups & n & No vomiting & Vomiting & $\begin{array}{l}\text { Chi- square } \\
\text { value }\end{array}$ & P value \\
\hline I (Palonosetron Group) & $\mathrm{n}=30$ & $28(93.3 \%)$ & $2(6.7 \%)$ & & \\
\hline II (Granisetron Group) & $\mathrm{n}=30$ & $22(73.3 \%)$ & $8(26.7 \%)$ & 16.0096 & $0.000334 \mathrm{p} \& 1 \mathrm{t} ; 0.05$. \\
\hline III (Ondansetron Group) & $\mathrm{n}=30$ & $14(46.7 \%)$ & $16(53.3 \%)$ & & \\
\hline Total & 90 & $64(71.1 \%)$ & $26(28.9 \%)$ & & \\
\hline
\end{tabular}




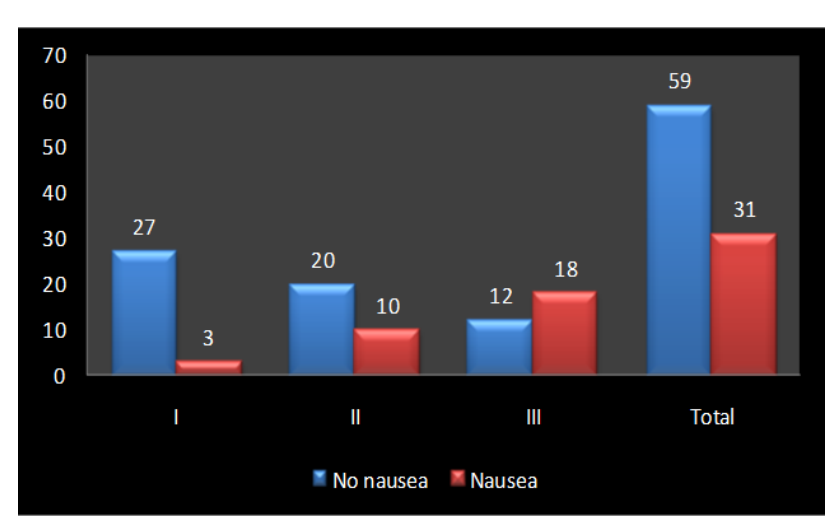

Figure 1: Incidence of nausea between different study groups $(n=90)$.

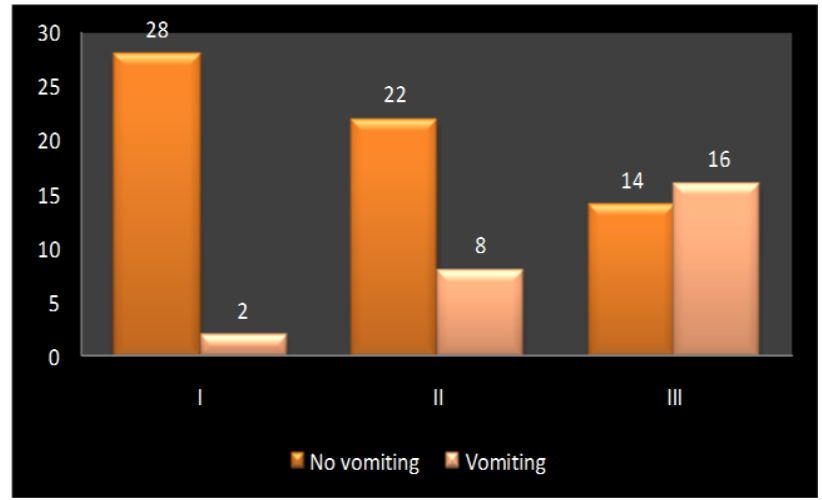

Figure 2: Incidence of vomiting in different study group $(n=90)$.

Table 4: Satisfactory level by verbal rating scale.

\begin{tabular}{|lllllll|}
\hline VRS & $\begin{array}{l}\text { Group I } \\
(\mathbf{n = 3 0})\end{array}$ & $\begin{array}{l}\text { Group II } \\
(\mathbf{n = 3 0})\end{array}$ & $\begin{array}{l}\text { Group III } \\
(\mathbf{n = 3 0})\end{array}$ & Total $(\mathbf{n = 9 0})$ & $\chi^{2}$ value & P value \\
\hline Not effective at all & $13.3 \%$ & $516.7 \%$ & $723.3 \%$ & $1314.4 \%$ & & \\
\hline Moderately effective & $620.0 \%$ & $1033.3 \%$ & $1343.3 \%$ & $2932.2 \%$ & & \\
\hline Effective & $1136.7 \%$ & $930.0 \%$ & $723.3 \%$ & $2730.0 \%$ & 13.75 & $0.032 \mathrm{~s}$ \\
\hline Excellent & $1240.0 \%$ & $640.0 \%$ & $310.0 \%$ & $2123.3 \%$ & & \\
\hline Total & $30100.0 \%$ & $30100.0 \%$ & $30100.0 \%$ & $90100.0 \%$ & \\
\hline
\end{tabular}

\section{Rescue antiemetic}

The incidence of rescue antiemetic in different study groups are shown in number and percentage in Table 5.

Our study found that heart rate difference among the groups at preoperative, intraoperative, postoperative upto
24 hours after recovery were not significant as shown in Table 6.

There was no significant changes in systolic and diastolic pressure among the groups of studied patients as shown in Table 7/8.

Table 5: Rescue antiemetic used in different study groups.

\begin{tabular}{|lllllll|}
\hline $\begin{array}{l}\text { Rescue } \\
\text { antiemetic } \\
\text { required }\end{array}$ & $\begin{array}{l}\text { Group I } \\
(\mathbf{n = 3 0})\end{array}$ & $\begin{array}{l}\text { Group II } \\
(\mathbf{n = 3 0})\end{array}$ & $\begin{array}{l}\text { Group III } \\
(\mathbf{n = 3 0})\end{array}$ & Total $(\mathbf{n = 9 0})$ & $\chi^{2}$ value & P value \\
\hline No & $2686.7 \%$ & $2170.0 \%$ & $1653.3 \%$ & $6370.0 \%$ & & \\
\hline Yes & $413.3 \%$ & $930.0 \%$ & $1446.7 \%$ & $2730.0 \%$ & 7.937 & $0.02 \mathrm{~s}$ \\
\hline Total & $30100.0 \%$ & $30100.0 \%$ & $30100.0 \%$ & $90100.0 \%$ & & \\
\hline
\end{tabular}

Table 6: Changes in heart rate in different study groups.

\begin{tabular}{|llllllllll|}
\hline & Pre & Intra & $\mathbf{3 0}$ min & 1 hour & 2 hour & 4 hour & 8 hour & 16 hour & 24 hour \\
\hline Group-I & $88.0 \pm 1.6$ & $88.8 \pm 2.4$ & $87.8 \pm 1.6$ & $89.2 \pm 1.8$ & $90.2 \pm 1.7$ & $89.0 \pm 2.2$ & $91.7 \pm 1.9$ & $88.6 \pm 1.7$ & $82.8 \pm 1.2$ \\
\hline Group-II & $89.1 \pm 3.1$ & $91.8 \pm 1.4$ & $91.4 \pm 2.3$ & $87.6 \pm 1.6$ & $88.0 \pm 1.6$ & $92.8 \pm 1.3$ & $96.6 .0 \pm 1.9$ & $85.0 \pm 0.8$ & $84.6 \pm 1.2$ \\
\hline Group-III & $87.8 \pm 1.5$ & $86.9 \pm 1.8$ & $88.0 \pm 1.6$ & $87.8 \pm 1.4$ & $85.6 \pm 0.6$ & $90.0 \pm 1.8$ & $93.6 \pm 2.2$ & $87.2 \pm 1.3$ & $82.2 \pm 0.7$ \\
\hline F value & 0.10 & 1.731 & 1.027 & 0.29 & 2.678 & 1.209 & 1.546 & 1.921 & 1.45 \\
\hline P value & $0.902 \mathrm{~ns}$ & $0.183 \mathrm{~ns}$ & $0.363 \mathrm{~ns}$ & $0.748 \mathrm{~ns}$ & $0.74 \mathrm{~ns}$ & $0.304 \mathrm{~ns}$ & $0.219 \mathrm{~ns}$ & $0.153 \mathrm{~ns}$ & $0.239 \mathrm{~ns}$ \\
\hline
\end{tabular}


Table 7: Variation in systolic BP in different study groups.

\begin{tabular}{|llllllllll|}
\hline & Pre & Intra & $\mathbf{3 0} \mathbf{~ m i n}$ & $\mathbf{1}$ hour & $\mathbf{2}$ hour & $\mathbf{4}$ hour & $\mathbf{8}$ hour & $\mathbf{1 6}$ hour & $\mathbf{2 4}$ hour \\
\hline Group-I & $119.5 \pm 3.3$ & $127.0 \pm 4.8$ & $119.3 \pm 5.5$ & $116.5 \pm 3.3$ & $120.5 \pm 2.9$ & $115.0 \pm 6.4$ & $126.0 \pm 3.2$ & $116.5 \pm 3.3$ & $116.0 \pm 2.8$ \\
\hline Group-II & $118.0 \pm 3.9$ & $135.0 \pm 2.4$ & $124.3 \pm 6.0$ & $123.0 \pm 2.9$ & $122.0 \pm 3.1$ & $129.3 \pm 6.5$ & $134.5 \pm 3.9$ & $123.0 \pm 2.9$ & $120.0 \pm 3.3$ \\
\hline Group-III & $121.0 \pm 2.3$ & $130.0 \pm 2.2$ & $138.3 \pm 5.4$ & $124.0 \pm 1.9$ & $122.0 \pm 2.2$ & $137.3 \pm 6.6$ & $134.0 \pm 2.9$ & $124.0 \pm 1.9$ & $117.0 \pm 2.2$ \\
\hline F value & 0.22 & 1.47 & 3.016 & 2.19 & 0.10 & 2.970 & 1.98 & 2.19 & 0.55 \\
\hline P value & $0.804 \mathrm{~ns}$ & $0.235 \mathrm{~ns}$ & $0.056 \mathrm{~ns}$ & $0.119 \mathrm{~ns}$ & $0.905 \mathrm{~ns}$ & $0.057 \mathrm{~ns}$ & $0.144 \mathrm{~ns}$ & $0.119 \mathrm{~ns}$ & $0.581 \mathrm{~ns}$ \\
\hline
\end{tabular}

Table 8: Variation in diastolic BP in different study groups.

\begin{tabular}{|llllllllll|} 
& Pre & Intra & $\mathbf{3 0 ~} \mathbf{m i n}$ & $\mathbf{1}$ hour & $\mathbf{2}$ hour & $\mathbf{4}$ hour & $\mathbf{8}$ hour & $\mathbf{1 6}$ hour & $\mathbf{2 4}$ hour \\
\hline Group-I & $\mathbf{7 7 . 5} \pm 2.5$ & $89.5 \pm 2.9$ & $81.0 \pm 2.5$ & $\mathbf{7 8 . 5} \pm 2.5$ & $81.0 \pm 2.4$ & $84.0 \pm 1.5$ & $86.2 \pm 2.4$ & $\mathbf{7 7 . 5 \pm 2 . 2}$ & $\mathbf{7 7 . 5 \pm 1 . 7}$ \\
\hline Group-II & $81.0 \pm 2.9$ & $92.5 \pm 1.7$ & $80.5 \pm 2.7$ & $79.0 \pm 1.5$ & $76.0 \pm 2.1$ & $84.5 \pm 1.6$ & $87.3 \pm 1.0$ & $80.0 \pm 2.4$ & $79.0 \pm 1.9$ \\
\hline Group-III & $81.0 \pm 1.9$ & $88.0 \pm 1.6$ & $89.3 \pm 3.4$ & $83.0 \pm 1.2$ & $83.5 \pm 2.4$ & $85.7 \pm 1.6$ & $88.5 \pm 1.7$ & $85.0 \pm 2.4$ & $79.0 \pm 1.3$ \\
\hline F value & 0.66 & 1.10 & 2.979 & 1.82 & 2.830 & .297 & .427 & 2.618 & 0.27 \\
\hline P value & $0.517 \mathrm{~ns}$ & $0.337 \mathrm{~ns}$ & $0.056 \mathrm{~ns}$ & $0.168 \mathrm{~ns}$ & $0.064 \mathrm{~ns}$ & $0.744 \mathrm{~ns}$ & $0.654 \mathrm{~ns}$ & $0.079 \mathrm{~ns}$ & $0.766 \mathrm{~ns}$ \\
\hline
\end{tabular}

\section{DISCUSSION}

Nausea and vomiting are among the most common postoperative complaints. These are frequently the cause of great distress to patients and it is often the worst memory of their hospital stay. ${ }^{18}$ The consequences of prolonged postoperative nausea and vomiting (PONV) range from unexpected admission of day patients, with its economic implications to physical, metabolic and psychological effect on the patients. ${ }^{19}$

Better anesthetic technique, identification of precipitating factors, use of new generation of antiemetics and improvement in operative techniques reduce the incidence and severity of PONV has been decreasing over the last 10 years. Despite these changes, there is still unacceptable frequency of PONV with incidences up to $85 \%$ reported in some studies. ${ }^{5}$

A study suggests that the incidence of postoperative nausea and vomiting has remained constant for decades with $20-30 \%$ of patients suffering from these unpleasant side effects. ${ }^{20}$ Thus PONV is likely to create considerable extra cost for health care system. The aetiology of PONV is complex and multifactorial. Factors associated with an increased risk of postoperative emesis include age, gender, obesity, a history of motion sickness and/or previous postoperative emesis, anxiety, menstruation, gastroparesis, pain, hypoxia, type of anaesthetic, hypotension and type and duration of the surgical procedure. $^{21}$

Patients undergoing laparoscopic surgery are at high risk for postoperative nausea and vomiting. Because most of them are female and due to instrumental manipulation release of humoral substance include 5hydroxytryptamine (5-HT) which may stimulate 5-HT receptor in the afferent vagus nerves triggering the emetic reflex chemoreceptor trigger zone and pneumoperitonium needed for laparoscopy has direct effect on postoperative nausea and vomiting. ${ }^{20}$

Yoshitaka Fujii and Hiroyoshi Tanaka ${ }^{22}$ studied the efficacy of the selective 5-hydroxytryptamine receptor antagonist granisetron with that of the traditional antiemetics droperidol and metoclopramide in the treatment of established PONV after laparoscopic surgery. ${ }^{23}$

In their study there were no significant group differences in patient's demographic or surgical characteristics. There was no significant difference in haemodynamic parameters - pulse, B.P and saturation of arterial oxygen. ${ }^{23}$ The number of patients who were emesis free (no nausea, retching or vomiting) was significantly higher in patients who received granisetron $(88 \%, 22 / 25)$, than who received droperidol $(60 \%, 16 / 25, \mathrm{P}=0.047)$ or metoclopramide $(55 \%, 14 / 25, \mathrm{P}=0.013){ }^{23}$

By comparing with this study, ${ }^{23}$ our study found that heart rate difference among the groups at preoperative, intraoperative, postoperative upto 24 hours after recovery were not significant. There was no significant changes in systolic and diastolic pressure among the groups of studied patients. The incidence of nausea in group-I 10\%, in group-II $33.3 \%$ and in group-III - $60.0 \%$. In our study, the incidence of "no nausea" was significantly higher in patients who received palonosetron $(90.0 \%, 27 / 30)$ than in those who received granisetron $(66.7 \%, 20 / 30$, $\mathrm{P}=0.028)$ or ondansetron $(40.0 \%, 12 / 30, \mathrm{P}=0.000)$.

The incidence of vomiting in group-I $(6.7 \%)$. In group-II $(26.7 \%)$ and group-III $(53.3 \%)$. In our study, the incidence of "no vomiting" was significantly higher in patients who received palonosetron $(93.3 \%, 28 / 30)$ than in those who received granisetron $(73.3 \%, 22 / 30$, $\mathrm{P}=0.037)$ or ondansetron $(46.7 \%, 14 / 30, \mathrm{P}=0.000)$. Also in the study, palonosetron was associated with greater 
patients satisfaction than granisetron and ondansetron $40 \%, 20 \%$ and $10 \%$ of patients, respectively $(\mathrm{P}=0.032)$. No need for another rescue antiemetic medication was achieved in $86.7 \%$ of patients with palonosetron, $70.0 \%$ with granisetron and $53.3 \%$ with ondansetron $(\mathrm{P}=0.02)$ in this study.

In the present study, 5 patients were excluded as laparoscopic procedures could not succeed and open cholecystectomy were done. To maintain the postoperative analgesia injection pethidine $(1.5 \mathrm{mg} / \mathrm{kg})$ was given intramuscularly 8 hourly and inj. ketorolac (30 $\mathrm{mg}$ ) was given I/M on demand. In our study, it was a great satisfaction that though injection pethidine was given to all patients of three groups for post-operative analgesia and sedation, there was no increase in frequency of nausea and vomiting episodes as its side effects, which were also probably blocked by inj. palonosetron, granisetron and ondansetron.

Our result showed that, Injection palonosetron $(1 \mathrm{mg})$ administered 10 minutes before reversal of anaesthesia is more effective than granisetron and ondansetron in the prevention and treatment of postoperative nausea and vomiting after laparoscopic cholecystectomy.

\section{CONCLUSION}

The present study was particularly designed to observe the incidence of nausea and vomiting and requirement of rescue antiemetic in postoperative period and also detect the patients' satisfaction by verbal rating scale after 24 hours of surgery.

After completion of the study it was found that palonosetron greatly reduced the incidence of postoperative nausea and vomiting, and also the requirement of rescue antiemetic in postoperative period than granisetron and ondansetron.

Patient was satisfied by using this drug. So this present randomized prospective comparative clinical study concluded that palonosetron is more effective in comparison to granisetron and ondansetron in the prevention and treatment of postoperative nausea and vomiting after laparoscopic cholecystectomy.

\section{ACKNOWLEDGEMENTS}

The authors would like to thank Dr. Manjula Bhargava \& Dr. Vineet Chaudhary for their valuable support throughout the study.

Funding: No funding sources

Conflict of interest: None declared

Ethical approval: The study was approved by the institutional ethics committee

\section{REFERENCES}

1. NCBI. Limitation: 'editorial', search term: 'PONV' Available at: http://www.ncbi.nlm.nih.gov/pubmed. Accessed 9 September 2010.

2. Kapur PA. The big 'little problem'. Anesth Analg. 1991;73:243-5.

3. Kranke Peter, Leopold HJ. Eberhart. Possibilities and limitations in the pharmacological management of postoperative nausea and vomiting. Eur $\mathbf{J}$ Anaesthesiol. 2011;28(11):758-65.

4. Royston D, Cox F. Anaesthesia: the patient's point of view. Lancet. 2003;362:1648-58.

5. Hernandez Conte AT. Postoperative nausea and vomiting: a review of antiemetic pharmacological interventions. Anaesth Pharmacol Physiol Rev. 1996;4:57-65.

6. M. F. M. Franck, Radtke C. C. Apfel, R. Kuhly, A. Baumeyer, C. Brandt, K. D. Wernecke, et al. Documentation of post-operative nausea and vomiting in routine clinical practice. J Int Med Res. 2010;38(3):1034-41.

7. Blinkhorne K. Prepared for a smooth recovery? Nursing Times. 1995;91(28):42-4.

8. Ernst E. The Economics of quality care. Postoperative Nausea and Vomiting. Cookham: Direct Publication Solutions; 1994.

9. Rowbotham D. Recognising risk factors. Nursing Times. 1995;91(28):44-6.

10. Gundzik K. Nausea and vomiting in the ambulatory surgical setting. Orthop Nurs. 2008;27:182-8.

11. Graumlich JF, Belknap SM, Bullard SA, Storm GA, Brunsman KS, Howerton JA. Pharmaceutical care of postoperative nausea and vomiting: balanced scorecard for outcomes. Pharmacotherapy. 2000;20:1365-74.

12. Yeasmeen Sabina, Rubina Yasmin, A. K. M. Akhtaruzzaman, U. H. Shahera Khatun. Intravenous granisetron, ondansetron and metoclopramide in the prevention and treatment of post-operative nausea and vomiting after laparoscopic cholecystectomy-a comparative study. J Bangladesh Soc Anaesthesiol. 2006;19(1):20-7.

13. Park SK, Cho EJ. A randomized, double-blind trial of palonosetron compared with ondansetron in preventing postoperative nausea and vomiting after gynaecological laparoscopic surgery. J Int Med Res. 2011;39(2):399-407.

14. Rojas Camilo, Marigo Stathis, Ajit G. Thomas, Edward B. Massuda, Jesse Alt, Jie Zhang, et al. Palonosetron exhibits unique molecular interactions with the 5-HT3 receptor. Anesth Analg. 2008;107(2):469-78.

15. Wilson AJ, Diemunsch P, Lindeque BG, Scheinin H, Helbo-Hansen HS, Kroeks MV, et al. Singledose iv granisetron in the prevention of postoperative nausea and vomiting. Br J Anaesth. 1996;76(4):515-8. 
16. Habib Ashraf S, Tong J. Gan. Evidence-based management of postoperative nausea and vomiting: a review. Can J Anesth. 2004;51(4):326-41.

17. Gan TJ, Meyer T, Apfel CC, Chung F, Davis PJ, Eubanks S, et al. Consensus guidelines for managing postoperative nausea and vomiting. Anesth Analg. 2003;97:62-71.

18. Rusch D, Eberhart LH, Wallenborn J, Kranke P. Nausea and vomiting after surgery under general anesthesia: an evidence-based review concerning risk assessment, prevention, and treatment. Dtsch Arztebl Int. 2010;107:733-41.

19. Ho KY, Chiu JW. Multimodal antiemetic therapy and emetic risk profiling. Ann Acad Med Singapore. 2005;34:196-205.

20. Watcha MF, White PF. Postoperative nausea and vomiting: its etiology, treatment and prevention. Anesthesiology. 1992;77:162-84.
21. Gondim CRN, Japiassú AM, Filho PEP, Almeida GF, Kalichsztein M, Nobre GF. Prevention and treatment of postoperative nausea and vomiting. Revista Brasileira de Terapia Intensiva. 2009;21(1):89-95.

22. Fujii Y, Saitoh Y, Tanaka H, Toyooka H. Prevention of PONV with granisetron, droperidol or metoclopramide in patients with post-operative emesis. Can J Anaesth. 1998;45:153-6.

23. Fujii Y, Tanaka H, Toyooka H. Optimal antiemetic dose of granisetron for preventing postoperative nausea and vomiting. Can J Anaesth. 1994;51:7947.

Cite this article as: Sharma N, Bhargava M, Chaudhary V, Sharma D, Mishra A, Chaudhary PK, Advani U, Kulshreshtha S. Comparison of antiemetic efficacy of palonosetron, ondansetron and granisetron in prevention of postoperative nausea and vomiting. Int Surg J 2015;2:549-55. 